Hiroyuki Arimura MD, Yoshimi lkemoto MD, Takao Ito MD, Junichi Yoshitake MD

\title{
Lack of effects of d-tubocurarine and pancuronium on the slow action potential of the guinea pig papillary muscle
}

\begin{abstract}
Inotropic effects of non-depolarizing muscle relaxants were examined with guinea pig ventricular papillary muscle depolarized to $-47 \mathrm{mV}$ in high $K$ Ba-Tyrode solution. Field stimulation of $0.1 \mathrm{~Hz}$ elicited the slow action potential, a measure of the calcium current. The amplitude, the duration at $0 \mathrm{mV}$ level and dV/dt of the action potential were monitored together with the contractile tension. Amelizal ( $3 \mathrm{mg} \cdot \mathrm{ml}^{-1}$ d-tubocurarine (d-tc) and $5 \mathrm{mg} \cdot \mathrm{ml}^{-1}$ chlorobutanol) depressed the four functions in a dose-dependent manner, while crystalline d-tc did not. Chlorobutanol (the antimicrobial preservative) had the same effects as Amelizol. Neither Mioblock (2 $\mathrm{mg}^{\mathrm{ml}} \mathrm{l}^{-1}$ pancuronium and unpublished preservative) nor crystalline pancuronium altered the functions. These findings suggest that the negative inotropic effect of Amelizol is not due to d-tc but to chlorobutanol, which may exert its effect by depressing the caicium current. The lack of change in the slow action potential seen with pancuronium may indicate no direct effect on the calcium current, thereby further suggesting absent direct belaadrenomimetic action of this agent.
\end{abstract}

Key words

NEUROMUSCULAR RELAXANTS: d-tubocurarine, pancuronium; MUSCLE, CARDIAC: slow action potential; ANTIMICROBIALS: chlorobutanol.

From the Department of Anaesthesiology, Faculty of Medicine, Kyushu University, Fukuoka, 812, Japan, where correspondence should be addressed to Dr. Ikemoto.
The importance of non-depolarizing muscle relaxants in clinical anaesthesia is widely recognized. Investigators have reported adverse effects of some of these agents. Intravenous administration of various commercial preparations of d-tubocurarine (d-tc) may induce arterial hypotension ${ }^{1}$ which was ascribed to a reduction in the peripheral vascular resistance ${ }^{2}$ caused by an increase in the plasma histamine level ${ }^{3}$ and/or ganglionic blockade..$^{4,5}$ The commercial preparations were shown to have a negative inotropic effect on the myocardium in vitro, and this effect was attributed to their preservatives. ${ }^{6.7}$ Carrier and Murphy further showed that elevation of the calcium ion concentration in the perfusate reversed the negative inotropic effect of Abbott vehicle 3386 and benzyl alcohol (a bacteriostatic preservative in Squibb's tubocurarine chloride). They did not, however, monitor the electrical phenomena of the cardiac muscle. Therefore it was not possible to elucidate where these agents exerted the effects in the sequence of excitation-contraction coupling.

In the present study, experiments were designed to assess the effects of a commercial preparation Amelizol $\left(3 \mathrm{mg} \cdot \mathrm{ml}^{-1} \mathrm{~d}\right.$-tc and $5 \mathrm{mg} \cdot \mathrm{ml}^{-1}$ chlorobutanol) on the slow inward current and the contractile tension by use of the slow action potential and the associated contraction of partially depolarized papillary muscle of guinea pig ventricle.

On the other hand we often observed tachycardia and hypertension after intravenous administration of Mioblock ( $2 \mathrm{mg} \cdot \mathrm{ml}^{-1}$ pancuronium and unpublished preservative). Tachycardia sometimes leads to serious hypotension in patients with valvular heart disease and may have adverse effects on the 
ischaemic heart muscle by increasing oxygen demand. These cardioacceleratory effects have been studied by many investigators ${ }^{8-12}$ and attributed to a direct action on the myocardium, ${ }^{13}$ a vagolytic action $2,14,15$ or an increase in catecholamine release. ${ }^{16,17}$

The present in vitro experiments were designed to study the inotropic effects of a commercial preparation (Mioblock) and crystalline pancuronium. It was possible to clarify the direct effects of the agents on the slow action potential and the contractile tension, because the preparation was dissociated from control of the central nervous system and because catecholamine release from the nerve endings in the myocardium was minimized by use of low frequency stimulation and a partially depolarized preparation.

\section{Methods}

Guinea pigs (300-400 g) were killed by a blow on the head and the heart was quickly excised. Papillary muscles with a diameter of at most $1 \mathrm{~mm}$ were dissected from the right ventricle and mounted in a recording chamber of $1 \mathrm{~mL}$ volume, which was perfused at a constant rate of $5 \mathrm{~mL} \cdot \mathrm{min}^{-1}$ with Tyrode solution of the following composition (mM): $\mathrm{NaCl} 137 ; \mathrm{KCl} 2.2 ; \mathrm{CaCl}_{2} 1.8 ; \mathrm{MgCl}_{2}$ 1.1; $\mathrm{NaH}_{2} \mathrm{PO}_{4}$ 0.4; $\mathrm{NaHCO}_{3} 12$; glucose 5.5. The solution was aerated with a mixture of 95 per cent $\mathrm{O}_{2}$ and five per cent $\mathrm{CO}_{2}$ and maintained at $36.0 \pm 0.5^{\circ} \mathrm{C}$.

The valvular end of the muscle was connected to a linear force-displacement transducer (UL-2; Shinkoh, Japan) for isometric tension measurement. Membrane potentials were measured with $3 \mathrm{M}$ $\mathrm{KCl}$-filled glass microelectrodes with a resistance of about 20 megohms. Potentials were led to an amplifier with high input impedance and negative capacitance adjustment (MEZ 7101; Nihon Kohden', Japan). Analog differentiation of the action potential (dV/dt) was obtained with an electronic differentiator with a time constant of 10 or 100 $\mu$ sec. For stimulation, rectangular current pulses were applied between the $\mathrm{Ag}-\mathrm{AgCl}$ plate electrode placed near the valvular end of the muscle and a small ring of $\mathrm{Ag}-\mathrm{AgCl}$ wire closely encircling the basal segment of the muscle, as described by Ehara and Inazawa. ${ }^{18}$ The stimuli were delivered at a rate of $0.1 \mathrm{~Hz}$ via an isolator connected to an electronic stimulator (SS 102J and SEN 1101; Nihon Kohden,
Japan). The stimulus duration was $2 \mathrm{msec}$ and the intensity was 1.5 times the threshold.

After equilibration for 30 to 60 minutes in normal Tyrode solution, the bath medium was replaced with high $\mathrm{K} \mathrm{Ba}$-Tyrode solution prepared by increasing $\mathrm{KCl}$ concentration to $22 \mathrm{mM}$ and adding $0.2 \mathrm{mM}$ $\mathrm{BaCl}_{2}$. No correction for osmolarity was made. Drugs were applied after more than 30 minutes of equilibration in the high $\mathrm{K}$ Ba-Tyrode solution. Action potential, its $\mathrm{dV} / \mathrm{dt}$ and contractile tension were monitored on an oscilloscope (5113; Tektronix, USA) and photographed. In some experiments a chart recorder (PMP 3004; Nihon Kohden, Japan) was also used. The action potential duration was measured at $0 \mathrm{mV}$ level.

Drugs used were Amelizol $\left(3 \mathrm{mg} \cdot \mathrm{ml}^{-1} \mathrm{~d}\right.$ tubocurarine chloride and $5 \mathrm{mg} \cdot \mathrm{ml}^{-1}$ chlorobutanol) (Yoshitomi, Japan), crystalline d-tubocurarine chloride (Nakarai, Japan), chlorobutanol (Nakarai, Japan), Mioblock ( $2 \mathrm{mg} \cdot \mathrm{ml}^{-1}$ pancuronium bromide and unpublished preservative) (Organon, Holland) and crystalline pancuronium bromide (Organon, Holland). All data considered were those from experiments where a single impalement of a cell was maintained throughout. All parameters were measured at about 20 minutes after application of the drugs. Recovery of about 90 per cent was achieved by washing the preparation for $30 \mathrm{~min}-$ utes. Data were analyzed using Student's t-test for paired data.

\section{Results}

The resting membrane potential of the papillary muscle in normal Tyrode solution was $-96.2 \pm 0.67$ $\mathrm{mV}$ (mean $\pm \mathrm{SEM})(\mathrm{n}=72)$. It was depolarized to $-47 \pm 0.67 \mathrm{mV}$ (mean \pm SEM) $(n=64)$ in high $\mathrm{K}$ Ba-Tyrode solution. The slow action potential and the contractile tension of the muscle were elicited by increasing the stimulus intensity (Figure $1 \mathrm{a}, \mathrm{b}$ ). Low concentrations of Amelizol did not affect the parameters significantly while higher concentrations markedly depressed the slow action potential and the contractile tension, without affecting the resting membrane potential. The depression was completely reversed when $\mathrm{Ca}$ ion concentration of the perfusate was doubled (Figure $1 \mathrm{c}, \mathrm{d}$ ). Similar results were obtained with four additional preparations. Figure 2 illustrates the effects of various concentrations of Amelizol on the parameters. Reduction in the action potential duration, maximum 

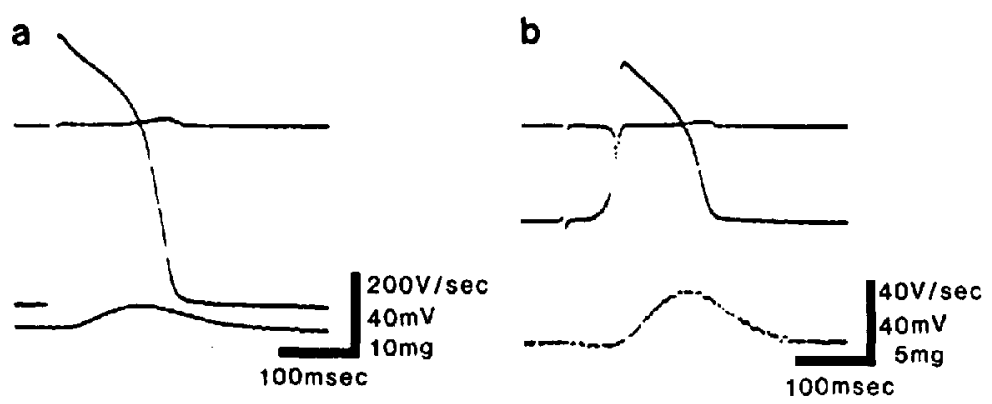

C

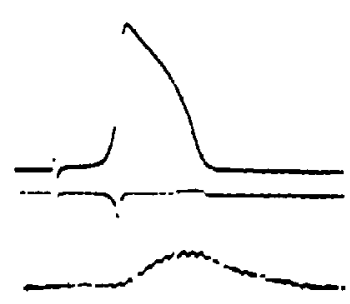

d

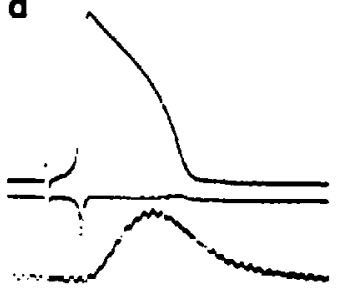

e

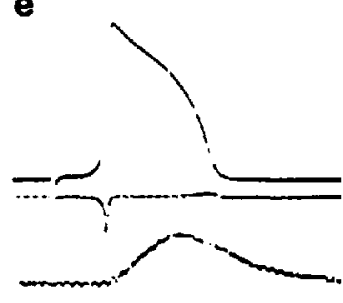

FIGURE 1 Depression of the slow action potential and the contractile tension by Amelizol and reversion by elevation of calcium ion concentration. (a) Action potential, its $\mathrm{dV} / \mathrm{dt}$ and contractile tension of guinea pig papillary muscle in normal Tyrode solution. (b) The slow action potential, its $\mathrm{dV} / \mathrm{dt}$ and the contractile tension in high $\mathrm{K}$ Ba-Tyrode solution. The $\mathrm{dV} / \mathrm{dt}$ reference line indicates $0 \mathrm{mV}$ level for the action potential. (c) Depression of the parameters by Amelizol $\left(40 \mathrm{mg} \cdot \mathrm{L}^{-1}\right)$. (d) Reversal of the depression by elevation of calcium ion concentration (1.8 $\mathrm{mM}$ to $3.6 \mathrm{mM}$ ) of the perfusate. (c) Recovery after washing with high $\mathrm{K}$ Ba-Tyrode solution for $30 \mathrm{~min}$. Calibrations for (b) apply also for (c), (d) and (e).

$\mathrm{dV} / \mathrm{dt}$ and the contractile tension was already significant with $20 \mathrm{mg} \cdot \mathrm{L}^{-1}$ Amelizol. All the parameters were reduced, in a concentration dependent manner.

Crystalline d-tc did not affect the slow action potential or the contractile tension, even at the highest concentration used $\left(40 \mathrm{mg} \cdot \mathrm{L}^{-1}\right)$ (Figure 3 ), while this concentration of Amelizol greatly reduced all the parameters (Figure 2). Chlorobutanol, the antimicrobial preservative in Amelizol, decreased the parameters significantly, in the same manner as Amelizol (Figure 4), As Amelizol contains $3 \mathrm{mg} \cdot \mathrm{ml}^{-1}$ of d-tc and $5 \mathrm{mg} \cdot \mathrm{ml}^{-1}$ of chlorobutanol, the concentration of chlorobutanol used in Figure 4 roughly corresponds to that contained in the Amelizol experiment (Figure 2). The depression by chlorobutanol $\left(50 \mathrm{mg} \cdot \mathrm{L}^{-1}\right)$ was also reversed in all of six experiments by elevation of calcium ion concentration in the perfusate.
Mioblock did not alter either the slow action potential or the associated contractile tension. Figure 5 shows the per cent change of the parameters from the control condition. The parameters were not affected significantly even at the highest concentration used $\left(20 \mathrm{mg} \cdot \mathrm{L}^{-1}\right)$. A high concentration of crystalline pancuronium bromide (20 $\left.\mathrm{mg} \cdot \mathrm{L}^{-1}\right)$ did not affect the parameters $(n=4)$.

\section{Discussion}

To elucidate the effects of drugs on the myocardium, it is important to study the pharmacologic actions on the ionic mechanisms of the action potential. In particular, with regard to inotropic effects, changes in the membrane calcium current have to be examined. Calcium ions which flow into the heart muscle cell during the action potential appear to release calcium ions from an intracellular storage site through a calcium induced calcium 


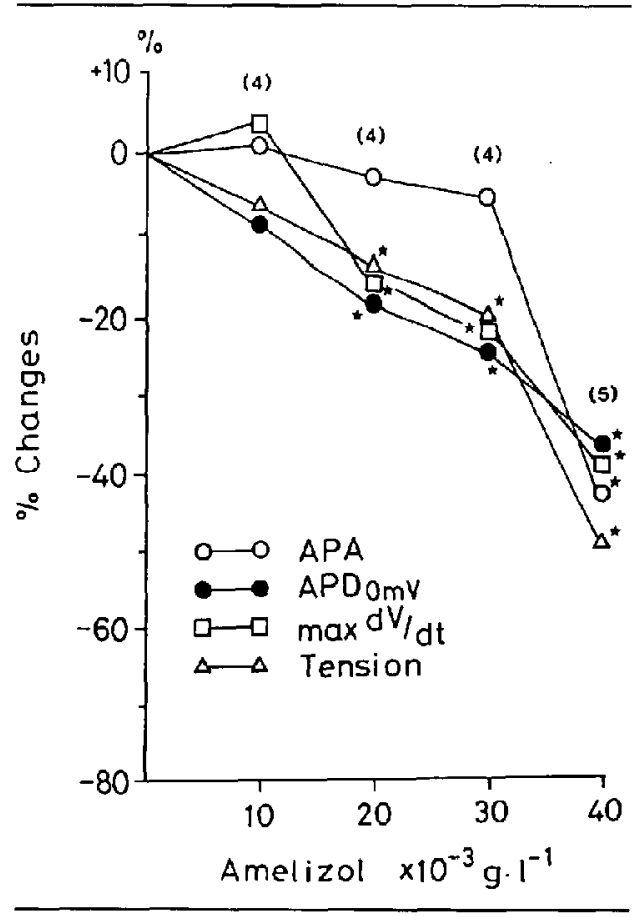

FIGURE 2 Effects of various concentrations of Amelizol on the slow action potential and the contractile tension. Amelizol reduced the action potential amplitude (APA), action potential duration at $0 \mathrm{mV}$ level $\left(\mathrm{APD}_{\mathrm{OmV}}\right)$, maximum upstroke velocity of action potential (max $d V / d t$ ) and contractile tension, in a dose dependent manner. Significant changes from the control value $(p<0.05)$ are indicated by asterisks. Number of experiments is shown in parentheses.

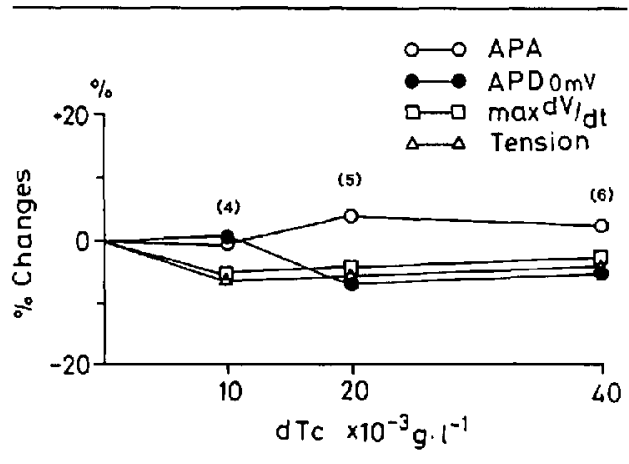

FIGURE 3 Effects of crystalline d-tubocurarine on the slow action potential and the contractile tension. Even a high. dose of the agent $\left(40 \mathrm{mg} \cdot \mathrm{L}^{-1}\right)$ did not affect the parameters. No significant change was observed with each concentration. Number of the experiments is shown in parentheses.

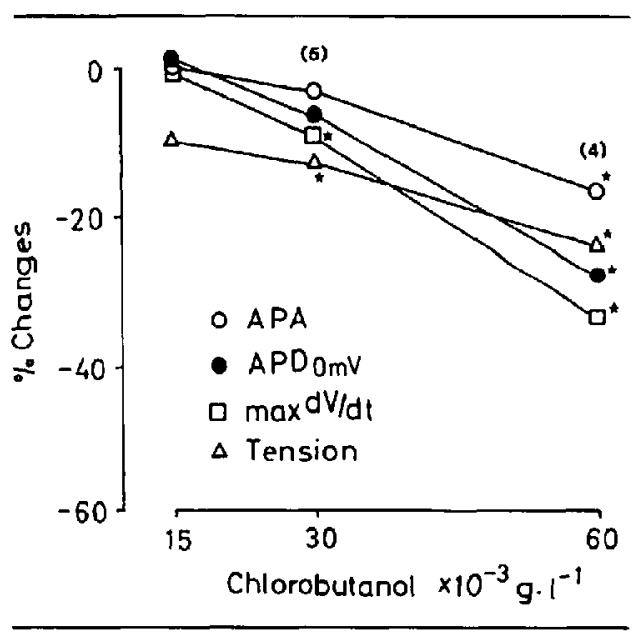

FIGURE 4 Effects of chlorobutanol on the slow action potential and the contractile tension. Chlorobutanol depressed the slow action potential and the contractile tension, in a dose dependent manner. Significant changes from the control value $(p<0.05)$ are indicated by asterisks. The effect was similar to that of Amelizol. Number of experiments is shown in parentheses.

release mechanism. ${ }^{19}$ Furthermore, the calcium current itself provides calcium ions to the intracellular storage site.

The slow action potential of the partially depolarized myocardium is known to be mediated by the slow channel and is useful for qualitative studies on the slow inward current which consists mainly of the calcium current. ${ }^{20}$ There are several reports on the inotropic effects of anaesthetics using this method. ${ }^{21-23}$ In the present study, the slow action potential of $22 \mathrm{mM} \mathrm{K}$-depolarized guinea pig papillary muscle was facilitated by $0.2 \mathrm{mM} \mathrm{BaCl}{ }_{2}$ with reduced membrane shunt resistance, as described by Ehara and Inazawa. ${ }^{18}$ At the membrane potential of about $-47 \mathrm{mV}$, the fast sodium current was almost completely inactivated, whereas the slow calcium current was little affected. ${ }^{24}$ The low concentration of Ba does not contribute appreciably to the upstroke velocity of the slow action potential, with normal calcium concentrations. The maximum rate of rise of the membrane action potential is considered to be a measure of the membrane current, in the present experiments, namely, the calcium inward current.

Carrier and Murphy ${ }^{7}$ and Dowdy et al. ${ }^{6}$ reported that the negative inotropic effect of the commercial 


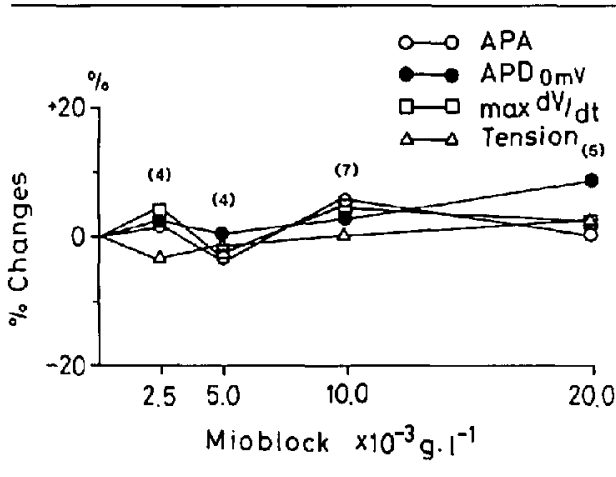

FIGURE 5 Effects of Mioblock on the slow action potential and the contractile tension. The drug did not affect the action potential or the contractile tension. No changes were significant at any concentration. Number of experiments is shown in parentheses.

preparations of d-tc in vitro was due to their preservatives. In the present study, we found that crystalline d-tc did not affect the slow action potential and that chlorobutanol significantly depressed the slow action potential and the associated contractile tension. These events were effectively reversed by elevation of calcium ion concentration in the perfusate. Our findings indicate that chlorobutanol exerts its negative inotropic effect via reduction in the calcium inward current, at least to some extent. Wingard and Cook reported that the serum concentration of $d$-tc was $9.6 \mathrm{mg} \cdot \mathrm{L}^{-1}$ immediately after and $3.86 \mathrm{mg} \cdot \mathrm{L}^{-1}$ two minutes after the intravenous injection of $0.3 \mathrm{mg} \cdot \mathrm{kg}^{-1}$ in man, with estimation of the initial apparent volume of distribution to be 3 to 3.6 liters. ${ }^{25}$ Higher concentrations of the drug may reach the myocardium at the very early circulation due to a smaller distribution volume for the drug. If the concentration of chlorobutanol declines in the same manner as d-tc, it may reach a level of more than $30 \mathrm{mg} \cdot \mathrm{L}^{-1}$ in the myocardial circulation, high enough to contribute to arterial hypotension. A concentration of $60 \mathrm{mg} \cdot \mathrm{L}^{-1}$ may be attained in the case of an overdose in clinical anaesthesia.

Stoelting reported that an intravenous injection of $10 \mathrm{ml}$ of Lilly's diluent (sodium chloride $7 \mathrm{mg}$. $\mathrm{ml}^{-1}$; sodium bisulfite $1 \mathrm{mg} \cdot \mathrm{ml}^{-1}$; chlorobutanol $5 \mathrm{mg} \cdot \mathrm{ml}^{-1}$ ) in halothane-nitrous oxide-oxygen anaesthetized men did not alter the mean arterial pressure significantly while Lilly's d-tc did. ${ }^{26}$ The discrepancy may be due to differences in species and preparations used. It may therefore be concluded that the negative inotropic effect of Amelizol (d-tubocurarine-chlorobutanol) is partly due to the depressant effect of the preservative (chlorobutanol) on the calcium inward current.

The mechanism of effects of pancuronium on the circulatory system is controversial. Muscarinic receptor blockade, beta-adrenergic stimulation and a direct positive inotropic effect on the myocardium have been reported. Iwatsuki et al. ${ }^{27}$ reported a positive inotropic effect of the drug on isolated canine ventricular trabeculae. They attributed the effect to a beta-adrenomimetic action, showing elimination of the effect in the presence of $10^{-6} \mathrm{M}$ propranolol. In their experiments, the drug may have increased catecholamine release from sympathetic nerve terminals in the cardiac muscle, as indicated by Domenech et al., ${ }^{17}$ because electrical field stimulation can release catecholamines from the nerve endings. ${ }^{28}$ In K-depolarized preparations in the present experiments, catecholamines were likely not released in any considerable amount because the stimulation frequency was low and because of the relative incapability of nerve fibres to generate action potentials in the depolarized state. Therefore, it is likely that the previously reported positive inotropic effect of pancuronium was mediated by increased catecholamine release from the nerve endings.

Seed and Chamberlain reported a direct inotropic effect of the drug on dog heart in vivo but it was not great enough to increase the stroke volume or the mean arterial pressure. ${ }^{13}$ Agoston et al. ${ }^{29}$ showed that the serum concentration of pancuronium two minutes after injection of $0.1 \mathrm{mg} \cdot \mathrm{kg}^{-1}$ was about $1.0 \mathrm{mg} \cdot \mathrm{L}^{-1}$ and Iwatsuki et al. calculated the concentration immediately after injection to be about $2.5 \mathrm{mg} \cdot \mathrm{L}^{-1}$, using Wingard's equation. ${ }^{27}$ Even taking into account a smaller initial distribution volume, our present findings show that clinical concentrations of pancuronium neither increase the calcium inward current nor exert a direct positive inotropic effect on the heart. Tachycardia and hypertension immediately after injection of the drug may be attributed to muscarinic blockade and/or increased release of catecholomines from the sympathetic nerve terminals. 


\section{Acknowledgements}

We thank $\mathbf{M}$. Ohara for comments on the manuscript. Crystalline pancuronium bromide was kindly provided by Organon (Molland)

\section{References}

1 Stoelting RK. The hemodynamic effects of pancuronium and d-tubocurarine in anesthetized patients. Anesthesiology 1972; 36: 612-5.

2 Coleman AJ, Downing JW, Leary WP, Moyes DG, Styles $M$. The immediate cardiovascular effects of pancuronium, alcuronium and tubocurarine in man. Anaesthesia 1972; 27: 415-22.

3 Iwatsuki K, Yusa T, Kataoka Y. Effects of muscle relaxants on ventricular contractile force in dogs. Tohoku J Exp Med 1965; 86: 9-18.

4 McCullough LS, Reier CE, Delaunois AL, Gardier $R$, Hamelberg $W$. The effects of d-tubocurarine on spontaneous post-ganglionic sympathetic activity and histamine release. Anesthesiology 1970; 33: 328-34.

5 Hughes R, Chapple DJ. Effects of non-depolarizing neuromuscular blocking agents on peripheral autonomic mechanisms in cats. Br J Anaesth 1976; 48: 59-67.

6 Dowdy EG, Holland WC, Yamanaka I, Kaya $K$. Cardioactive properties of d-tubocurarine with and without preservatives. Anesthesiology 1971; 34: 256-61.

7 Carrier $O \mathrm{Jr}$, Murphy JC. The effects of dtubocurarine and its commercial vehicles on cardiac function. Anesthesiology 1970; 33: 627-34.

8 Loh $L$. The cardiovascular effects of pancuronium bromide. Anaesthesia 1970; 25: 356-63.

9 McIntyre JWR, Gain EA. Initial experience during the clinical use of pancuronium bromide. Anesth Analg 1971; 50: 813-8.

10 Kelman $G R$, Kennedy $B R$. Cardiovascular effects of pancuronium in man. $\mathrm{Br} \mathrm{J}$ Anaesth 1971; 43 : 335-8.

11 Gertel M, Fox GS, Rabow FI, Graham DH. The cardiovascular effects of pancuronium during halothane anaesthesia. Can Anaesth Soc J 1972; 19: 599-606.

12 Edwards RP, Miller RD, Roizen MF et al. Cardiac responses to imipramine and pancuronium during anaesthesia with halothane or enflurane. Anesthesiology 1979 ; 50: 421-5.
13 Seed RF, Chamberlain JH. Myocardial stimulation by pancuronium bromide. Br J Anaesth 1977; 49: 401-7.

14 Saxena $P R$, Bonta $I L$. Mechanism of selective vagolytic action of pancuronium bromide. Specific blockade of cardiac muscarinic receptors. Eur J Pharmacol 1970; 11:332-41.

15 Duke $P C$, Fung $H$, Gartner $J$. The myocardial ef fects of pancuronium. Can Anaesth Soc J 1975; 22: 680-6.

16 Nana A, Cardan E. Domokos M. Blood catecholamine changes after pancuronium. Acta Anaesthesiol Scand 1973; 17: 83-7.

17 Domenech JS, Garcia RC, Sasiain JMR, Loyola AQ, Oroz JS. Pancuronium bromide: An indirect sympathomimetic agent. Br J Anaesth 1976; 48: 1143-8.

18 Ehara T, Inazawa M. Calcium-dependent slow action potentials in potassium-depolarized guineapig ventricular myocardium enhanced by barium ions. Naunyn-Schmiedeberg's Arch Pharmacol 1980; 315: 47-54.

19 Endo $M$. Mechanism of calcium-induced calcium release in the SR membrane. In: Ohnishi ST, Endo M, eds. The mechanism of gated calcium transport across biological membranes. New York: Academic Press, 1981: 257-64.

20 Schneider JA, Sperelakis $N$. Slow $\mathrm{Ca}^{2+}$ and $\mathrm{Na}^{+}$ responses induced by isoproterenol and methylxanthines in isolated perfused guinea pig hearts exposed to elevated $\mathrm{K}^{+}$. J Mol Cell Cardiol 1975; 7: 249-73.

21 Ikemoto $Y$. Reduction by thiopental of the slowchannel-mediated action potential of canine papillary muscle. Pflüger's Arch 1977; 372: 285-6.

22 Lynch $C$, Vogel $S$, Sperelakis $N$. Halothane depression of myocardial slow action potentials. Anesthesiology 1981; 55: 360-8.

23 Lynch C, Vogel S, Pratila MG, Sperelakis N. Enflurane depression of myocardial slow action potentials. J Pharmacol Exp Ther 1982; 222: 405-9.

24 Reuter $H$. Divalent cations as charge carriers in excitable membranes. In: Barker PF, Ructer $\mathrm{H}$, eds. Calcium movement in excitable cells. New York: Pergamon Press, 1975: 55-97.

25 Wingard $L B$, Cook DR. Pharmacodynamics of tubocurarine in humans. Br J Anaesth 1976; 48: 839-45.

26 Stoelting $R K$. Blood-pressure responses to 
d-tubocurarine and its preservatives in anesthetized patients. Anesthesiology 1971; 35: 315-7.

27 Iwatsuki N, Hashimoto Y. Amaha K, Obara S, Iwatsuki $K$. Inotropic effects of non-depolarizing muscle relaxants in isolated canine heart muscle. Anesth Analg 1980; 59: 717-21.

28 Blinks $J R$. Field stimulation as a means of effecting the graded release of autonomic transmitters in isolated heart muscle. J Pharmacol Exp Ther 1966; 151: 221-35.

29 Agoston S, Crul JF, Kerston UW, Scaf AHJ. Relationship of serum concentration of pancuronium to its neuromuscular activity in man. Anesthesiology 1977; 47: 509-12.
Résumé

Les effets inotropes des relaxants musculaires non dépolarisants ont été étudiés avec des muscles papillaires ventriculaires de cobayes dépolarisés à -47 mV dans un bain de solution a haute concentration de potassiumbarium-Tyrode. Un champ de stimulation de $0.1 \mathrm{~Hz}$ a provoqué un potentiel d'action lent représentant une mesure du courant calcique. L'amplitude ainsi que la durée du potentiel d'action à $0 \mathrm{mV}$ et le dV/dt ont été étudiées en même temps que la force contractile. L'amelizol (3 $\mathrm{mg} \cdot \mathrm{ml}^{-1}$ d-tubocurarine (d-tc) et $5 \mathrm{mg} \cdot \mathrm{ml}^{-3}$ chlorobutanol) a provoqué une dépression des paramètres dépendamment de la dose administrée alors que la d-tc crystalline n'a provoqué aucun changement. Le chlorobutanol (le préservatif bactériostatique) a eu les mêmes effets que l'amelizol. Ni le mioblock ( $2 \mathrm{mg} \cdot \mathrm{ml}^{-1}$ pancuronium et préservatif non publié) ni le pancuronium crystalline n'ont altéré les paramètres. Ces résultats suggèrent que les effets inotropes négatifs de l'amelizol ne sont pas dûs a la d-tc mais au chlorobutanol qui excerce ses effets en déprimant les courants caiciques. L'absence de changement dans le potential d'action lent observé avec le pancuronium peut indiquer qu'il n'a aucun effet direct sur les courants calciques suggérant ainsi l'absence d' effet direct bêta-adrinomimétique de cet agent. 